University of Nebraska - Lincoln

DigitalCommons@University of Nebraska - Lincoln

\title{
Nesting Biology of Three Grassland Passerines in the Northern Tallgrass Prairie
}

\author{
Maiken Winter \\ State University of New York \\ Douglas $\mathrm{H}$. Johnson \\ USGS Northern Prairie Wildlife Research Center, Douglas_H_Johnson@usgs.gov \\ Jill A. Shaffer \\ USGS Northern Prairie Wildlife Research Center, jshaffer@usgs.gov \\ W. Daniel Svedarsky \\ University of Minnesota
}

Follow this and additional works at: https://digitalcommons.unl.edu/usgsnpwrc

Part of the Other International and Area Studies Commons

Winter, Maiken; Johnson, Douglas H.; Shaffer, Jill A.; and Svedarsky, W. Daniel, "Nesting Biology of Three Grassland Passerines in the Northern Tallgrass Prairie" (2004). USGS Northern Prairie Wildlife Research Center. 241.

https://digitalcommons.unl.edu/usgsnpwrc/241

This Article is brought to you for free and open access by the US Geological Survey at DigitalCommons@University of Nebraska - Lincoln. It has been accepted for inclusion in USGS Northern Prairie Wildlife Research Center by an authorized administrator of DigitalCommons@University of Nebraska - Lincoln. 


\title{
NESTING BIOLOGY OF THREE GRASSLAND PASSERINES IN THE NORTHERN TALLGRASS PRAIRIE
}

\author{
MAIKEN WINTER, ${ }^{1.4 .5}$ DOUGLAS H. JOHNSON, ${ }^{2}$ JILL A. SHAFFER, ${ }^{2}$ AND \\ W. DANIEL SVEDARSKY ${ }^{3}$
}

\begin{abstract}
Basic nesting information on grassland passerines is needed for improving grassland bird management. Among the information needs are (1) the suitability of nesting habitat, (2) periods during the breeding season in which birds are most vulnerable to disturbances, and (3) how to fit grasslands into a prioritization scheme for conservation. Comparisons of nesting parameters among grassland species will help identify important management considerations. We describe and compare nest-site characteristics, nesting phenology, clutch size, hatching and fledging success, and brood parasitism by Brown-headed Cowbirds (Molothrus ater) for three grassland passerine species nesting in tallgrass prairie of northwestern Minnesota and southeastern North Dakota. During 1998-2002, we found 793 Clay-colored Sparrow (Spizella pallida), 687 Savannah Sparrow (Passerculus sandwichensis), and 315 Bobolink (Dolichonyx oryzivorus) nests. These species differed in many aspects of their breeding ecology. Clay-colored and Savannah sparrows initiated their nests almost 2 weeks earlier than Bobolinks, with peak nesting occurring in June. Clutch size was lower (3.77 \pm 0.03 SE) for Claycolored Sparrows than Savannah Sparrows $(4.13 \pm 0.05)$ and Bobolinks $(5.25 \pm 0.08)$. The number of host eggs hatched per nest was higher in Bobolinks (3.46 \pm 0.20$)$ than in Clay-colored Sparrows $(2.52 \pm 0.09)$ and Savannah Sparrows $(2.41 \pm 0.11)$, but the number of young fledged per Bobolink nest (1.97) was similar to that of Savannah Sparrows (2.01). Clay-colored Sparrows fledged only 1.35 host young per nest. Mayfield nest success was higher for Savannah Sparrows (31.4\%) than for Clay-colored Sparrows (27.4\%) or Bobolinks $(20.7 \%)$. The main cause of nest failure was nest predation: predation in Clay-colored Sparrows (47.9\%) was higher than in Savannah Sparrows (33.5\%) but similar to Bobolinks (41.8\%). Brood parasitism was lower in Clay-colored Sparrows (5.1\%) than in Bobolinks $(10.8 \%)$, and intermediate $(6.7 \%)$ in Savannah Sparrows. Compared with most other studies, grassland bird nests in our study area were more successful and less frequently parasitized; thus, northwestern Minnesota and southeastern North Dakota appear to provide important breeding habitat for grassland birds. Received 5 August 2003, accepted 29 July 2004.
\end{abstract}

Even though many species of grassland birds have experienced sharp population declines in the last four decades (Peterjohn and Sauer 1999), we still know little about the natural histories of most grassland-nesting bird species. To better understand these population declines and to develop effective management guidelines, we need basic information on the natural history of the species, including knowledge of nesting ecology. Specifically, more information is needed on (1) nest-site characteristics - to determine whether a specific habitat is suitable for nesting of a given

\footnotetext{
' State Univ. of New York, College of Environmental Sciences and Forestry, 1 Forestry Dr., Syracuse, NY 13210, USA.

${ }^{2}$ U.S. Geological Survey, Northern Prairie Wildlife Research Center, 8711 37th St. SE, Jamestown, ND 58401 , USA.

${ }^{3}$ Northwest Research and Outreach Center, Univ. of Minnesota, Crookston, MN 56716, USA.

${ }^{4}$ Current address: Lab. of Ornithology, Cornell Univ., 159 Sapsucker Woods Rd., Ithaca, NY 14850, USA.

s Corresponding author; e-mail: mw267@cornell.edu
}

species, (2) the timing of nesting and changes in breeding performance (clutch size and nest success) over the breeding season-to determine the periods in which grassland birds are most vulnerable to disturbances such as haying, and (3) general breeding performance of a species [including clutch size, hatching and fledging success, and brood parasitism by Brown-headed Cowbirds (Molothrus ater)]to prioritize prairie patches in conservation plans. A comparison of these parameters among species will indicate which should be considered in managing for a given species and whether species are likely to respond similarly to certain management actions. Such comparisons might also suggest whether indicator species would be valid tools for managing grassland birds.

In this paper, we describe and compare breeding parameters of three grassland species nesting in some of the largest patches of native tallgrass prairie remaining in Minnesota and North Dakota: Clay-colored Sparrow (Spizella pallida), Savannah Sparrow (Passerculus sandwichensis), and Bobolink (Dolicho- 
TABLE 1. Number $(n)$ and combined area of study plots, and number of nests found for Clay-colored Sparrows (CCSP), Savannah Sparrows (SAVS), and Bobolinks (BOBO) in tallgrass prairie in Minnesota (Crookston and Glyndon regions) and North Dakota (Sheyenne National Grassland), 1998-2002.

\begin{tabular}{lcrrrrr}
\hline Region & Year & $n$ & $\begin{array}{c}\text { Area } \\
\text { (ha) }\end{array}$ & CCSPa & SAVs & BOBO \\
\hline Crookston & 1998 & 10 & 101.94 & 22 & 49 & 23 \\
& 1999 & 12 & 124.72 & 86 & 150 & 27 \\
& 2000 & 11 & 121.37 & 32 & 143 & 24 \\
& 2001 & 12 & 120.58 & 119 & 135 & 69 \\
Glyndon & 2002 & 3 & 40.52 & 13 & 29 & 11 \\
& 1998 & 11 & 115.06 & 75 & 21 & 25 \\
& 1999 & 9 & 95.33 & 119 & 25 & 20 \\
Sheyenne & 2000 & 9 & 95.33 & 93 & 25 & 18 \\
& 2001 & 10 & 104.23 & 63 & 20 & 31 \\
& 1999 & 9 & 101.13 & 55 & 27 & 9 \\
& 2000 & 8 & 99.86 & 62 & 44 & 22 \\
\hline
\end{tabular}

a Number of nests found differs from that given in the following tables because not all nests could be used for each analysis.

nyx oryzivorus). During 1966-1999, these species declined in abundance across North America (Sauer et al. 2003).

The breeding ecology of our focal species is summarized in Knapton (1994) and Dechant et al. (2003a) for Clay-colored Sparrows; in Wheelwright and Rising (1993) and Swanson (2003) for Savannah Sparrows; and in Martin and Gavin (1995), Swanson (1996), and Dechant et al. (2003b) for Bobolinks. Most studies in these reviews had been conducted in portions of the species' ranges different from our study area or on island populations (for Savannah Sparrows; Dixon 1978, Wheelwright and Mauk 1998), or they were based on relatively small sample sizes (Lein 1968, Koford 1999). Nesting data collected in relatively large and intact grassland habitats are expected to reflect higher breeding success and lower brood parasitism by Brown-headed Cowbirds than documented in other regions (Herkert et al. 2003). Data from such "highquality" areas, therefore, can serve as a baseline for comparisons with other habitats. Such data are often lacking because large, intact patches of prairie are rare, and sample sizes are low because nests can be difficult to locate (Winter et al. 2003). The large number of nests $(n=1,795)$ that we found over a large regional (three regions approximately $50 \mathrm{~km}$ apart) and temporal (1998-2002) scale in some of the largest remnants of native tallgrass prairie likely provide reliable baseline data for future prioritization schemes.

\section{METHODS}

Study area.-We searched for grassland bird nests in 33 permanent study plots that were established in patches of native prairie located in three regions of the northern tallgrass prairie: the Crookston and Glyndon regions in northwestern Minnesota (19982002), and the Sheyenne region at Sheyenne National Grassland in southeastern North Dakota (1999-2001; Table 1). The Crookston and Sheyenne regions were located about 50 $\mathrm{km}$ north and about $50 \mathrm{~km}$ southwest, respectively, from the centrally located Glyndon region. In 2002, our study was limited to three plots in the Crookston region. All prairie patches were on U.S. Fish and Wildlife Service, U.S. Forest Service, State of Minnesota, or Nature Conservancy lands (Winter et al. 2001). Prairies in the Crookston and Glyndon regions were managed with prescribed burning, whereas Sheyenne prairies were managed with rotational grazing. Because management regime was confounded with region, we could not differentiate between management and regional effects, and therefore did not address management questions.

Study plots were selected based on uniformity of vegetation structure within and among plots, with a preference for areas of sparse cover by shrubs (mostly western snowberry Symphoricarpos occidentalis, and meadowsweet Spiraea alba) or trees (quaking aspen Populus tremuloides and willow Salix spp). 
The median (5th-95th percentile) cover by shrubs and trees within study plots was $0.7 \%$ $(0-12 \%)$, and the median (5th-95th percentile) cover by shrubs and trees within $1 \mathrm{~km}$ of study plots was $9.6 \%(1.5-29.3 \%)$. Some study plots were purposefully chosen adjacent to areas with high percent tree cover for evaluating landscape influence on breeding grassland birds (Winter et al. 2001; MW unpubl. data). The number of study plots varied slightly among years, depending on accessibility and burning regime (Table 1). Study plots were established by placing wooden stakes or flags at 50-m intervals along parallel transects that were $100 \mathrm{~m}$ apart. Depending on the size of the prairie patch, the size of study plots varied between 1.65 and 20.64 ha (mean = $11.22 \pm 0.88 \mathrm{ha}$ ), with small prairie patches containing smaller study plots than large patches.

Field methods.-We searched for nests of the three most common grassland birds, Claycolored and Savannah sparrows and Bobolinks, between 15 May and 31 July each year. Nests were found by flushing birds from nests while walking systematically or haphazardly through the study plots, or by behavioral observations (see Winter et al. 2003). We marked each nest with a pink surveyor flag 5 $m$ north of the nest and revisited nests every 2-4 days to determine outcome. A nest was considered successful if at least one young of the parental species fledged, and it was considered parasitized if it contained at least one egg or young of a Brown-headed Cowbird. The number of young fledged was assumed to be equal to the number of young observed on the last nest check if we did not find any indication of nest loss. We determined nest initiation dates by backdating nests with known hatching or fledging dates, assuming that one egg was laid per day and that incubation started with the last egg laid.

After fledging or failure, we measured nestsite characteristics at five locations: directly at the nest and $0.5 \mathrm{~m}$ from the nest in each cardinal direction (Winter 1999). At each location we estimated percent cover of bare ground, grass, forb, litter (dead plant material), and shrub within a $20 \times 50 \mathrm{~cm}$ Daubenmire frame (Daubenmire 1959). We placed a meter stick about $5 \mathrm{~cm}$ from each outer corner of the Daubenmire frame to measure the height of the highest plant touching the stick ("vegetation height") and litter depth. "Litter depth" was defined as the depth at which dead plant material lying at an angle of less than $45^{\circ}$ completely covered a ruler when viewed from the side. We placed a Robel pole (Robel et al. 1970) in the middle of each Daubenmire frame and took visual obstruction readings to the nearest $0.5 \mathrm{dm}$ at a distance of $4 \mathrm{~m}$ from each cardinal direction. We determined the average values for ground cover, vegetation height, litter depth, and visual obstruction for the five locations, and used those average values in all analyses. At each nest, we measured the height $(\mathrm{cm})$ above ground of the bottom of the nest cup and determined the nest substrate (bare ground, grass, forb, litter, or shrub). "Nest substrate" was defined as the substrate on which $>50 \%$ of the nest was built. We also estimated what percent of a nest was covered by vegetation when viewed from above, and the distance $(\mathrm{m})$ between the nest and the closest shrub and tree.

Data analyses.-Winter et al. (in press) demonstrated that nest success did not vary enough among years and regions to be detected statistically. Therefore, we combined data from all regions and years. However, because nesting parameters will always vary somewhat among regions and years, we took this variation into account by including region and year as random effects in all analyses. We also included year as a repeated effect, because nests were found on the same prairies during several years. We compared nest-site characteristics, nest phenology, and different parameters of breeding performance among species with the Tukey-Kramer test of multiple comparisons in PROC MIXED (SAS Institute, Inc. 1999). We analyzed data on (1) the initiation dates for the first nest; (2) the percentage of nests with bare ground, litter, forb, or shrubs as the main substrate; (3) the percentages of unsuccessful nests, nests with partial depredation, and parasitized nests; and (4) the average values for nest-site characteristics, clutch size, number of eggs hatched, and number of young fledged. In each analysis, each species-year-study plot combination was represented by a single data point. For all analyses except nest initiation and clutch size, we excluded study plots on which we found fewer than five nests of a given species; thus, 
sample size $(n)$ equals the number of study plots on which we found $>4$ nests of a species. The number of nests used to determine clutch size, hatching success, and fledging success differs from the number of nests used to describe nest-site characteristics because we were not able to relocate some nests after they were terminated. In addition, some nests were part of an allied study in which we used miniature video cameras at nest sites to determine the types of nest predators visiting a nest. We did not include nest-fate data from camera-monitored nests because of the potential influence that video cameras had on nest success (Pietz and Granfors 2000), but we did include those nests in our summary of nestsite characteristics.

While we evaluated whether a species' clutch size changed during the breeding season using PROC MIXED (SAS Institute, Inc. 1999), the binomial (success/fail) nature of data on nesting success made other analysis procedures necessary. For these data, we used the GLIMMIX macro (Wolfinger and O'Connell 1993) in conjunction with Shaffer's logistic-exposure model (Shaffer 2004, see below). For the analysis of clutch size, we excluded nests that were discovered after hatching to minimize the possibility that clutch size had been reduced by partial predation. We used Akaike's Information Criterion (AIC; Anderson et al. 2000) to determine which of seven different date models best described seasonal changes in clutch size and nest success. The date models included date in linear, squared, linear plus squared, logarithmic, exponential, linear plus exponential, or categorical form. To compare clutch size, number of eggs hatched, and number of fledglings between parasitized and nonparasitized nests of the same species, we used PROC TTEST (SAS Institute, Inc. 1999). Results are presented as percentages or as means $\pm \mathrm{SE}$.

We calculated two estimates of nest success: (1) Mayfield estimates (Mayfield 1975), and (2) estimates from logistic-exposure models (Shaffer 2004). To calculate the number of exposure days for the Mayfield estimate, we determined the mid-point between the penultimate and the ultimate date of nest checking. The number of exposure days for nests with unknown fate included only the number of days until the penultimate date of nest check- ing (Manolis et al. 2000). Standard errors for daily nest survival rates follow Johnson (1979). Whereas the Mayfield method requires nests to be grouped into discrete categories, the logistic-exposure method allows each nest to have unique values of covariates. Therefore, this method is more appropriate when investigating factors that might influence nest success. For this analysis, we split the data into two nesting intervals (before and after the penultimate check date), such that the number of observation intervals used in the analysis is greater than the number of nests. To estimate the probability of nest survival over the nesting period (incubation and nestling stages), we took the daily nest survival rates derived from the Mayfield estimates and from the logistic-exposure models to the following exponents: 20 (days) for Clay-colored Sparrow, 21.5 for Savannah Sparrow, and 24 for Bobolink (Ehrlich et al. 1988).

\section{RESULTS}

We found 1,795 nests of the three species: 793 Clay-colored Sparrow nests, 687 Savannah Sparrow nests, and 315 Bobolink nests. Nest-site characteristics of Clay-colored Sparrows differed greatly from those of Savannah Sparrows and Bobolinks, whereas nest sites of Savannah Sparrows and Bobolinks were more similar to each other (Table 2). Clay-colored Sparrows placed their nests more frequently in shrubs and less frequently in litter. Consequently, Clay-colored Sparrow nests were higher above ground, the vegetation surrounding the nest had less grass and litter cover and more shrub cover, vegetation was taller, visual obstruction readings were higher, and nests were situated closer to shrubs and trees than those of the other two species. Nest substrates were similar for Savannah Sparrows and Bobolinks. Both species placed their nests most frequently within thick clumps of litter and least frequently in shrubs, but they also differed in several nest-site characteristics (Table 2): Savannah Sparrow nests had a higher percentage of nest cover, and the area surrounding the nests had a slightly higher percentage of bare ground. In addition, vegetation was shorter at Savannah Sparrow nests than at Bobolink nests.

The earliest nest initiation dates were 17 May for Clay-colored Sparrows, 15 May for 
TABLE 2. Nest-site characteristics of three passerine species nesting in tallgrass prairie in Minnesota and North Dakota, 1998-2002. Means sharing the same letter (within rows) are not significantly different $(P>0.05)$.

\begin{tabular}{|c|c|c|c|c|c|c|}
\hline \multirow[b]{2}{*}{ Nest characteristic ${ }^{a}$} & \multicolumn{2}{|c|}{ Clay-colored Sparrow } & \multicolumn{2}{|c|}{ Savannah Sparrow } & \multicolumn{2}{|c|}{ Bobolink } \\
\hline & $\dot{x}$ & SE & $\bar{x}$ & SE & $\bar{x}$ & SE \\
\hline \multicolumn{7}{|l|}{ Nest substrate $(\%)^{\mathrm{b}}$} \\
\hline Bare ground & $0.2 \mathrm{~A}$ & 1.5 & $5.9 \mathrm{~B}$ & 1.7 & $3.4 \mathrm{AB}$ & 2.1 \\
\hline Grass & $8.9 \mathrm{~A}$ & 2.2 & $9.5 \mathrm{~A}$ & 2.7 & $13.9 \mathrm{~A}$ & 3.2 \\
\hline Forb & $10.4 \mathrm{~A}$ & 1.8 & $1.1 \mathrm{~B}$ & 2.1 & $6.0 \mathrm{AB}$ & 2.6 \\
\hline Litter & $33.2 \mathrm{~A}$ & 3.3 & $79.5 \mathrm{~B}$ & 3.9 & $74.2 \mathrm{~B}$ & 4.8 \\
\hline Shrub & $42.9 \mathrm{~A}$ & 2.4 & $0.3 \mathrm{~B}$ & 2.9 & $0.7 \mathrm{~B}$ & 3.5 \\
\hline Nest cover $(\%)$ & $71.0 \mathrm{AB}$ & 1.8 & $77.2 \mathrm{~A}$ & 2.0 & $67.1 \mathrm{~B}$ & 2.5 \\
\hline Nest height (cm) & $13.5 \mathrm{~A}$ & 0.4 & $0.2 \mathrm{~B}$ & 0.5 & $0.1 \mathrm{~B}$ & 0.6 \\
\hline \multicolumn{7}{|l|}{ Ground cover (\%) } \\
\hline Bare ground & 0.9 AB & 0.3 & $1.7 \mathrm{~B}$ & 0.3 & $0.3 \mathrm{~A}$ & 0.4 \\
\hline Grass & $27.3 \mathrm{~A}$ & 1.2 & $35.1 \mathrm{~B}$ & 1.4 & $35.3 \mathrm{~B}$ & 1.7 \\
\hline Forb & $21.1 \mathrm{~A}$ & 1.3 & $20.2 \mathrm{~A}$ & 1.5 & $22.6 \mathrm{~A}$ & 1.9 \\
\hline Litter & $29.2 \mathrm{~A}$ & 1.3 & $41.5 \mathrm{~B}$ & 1.5 & $38.6 \mathrm{~B}$ & 1.9 \\
\hline Shrub & $21.4 \mathrm{~A}$ & 0.1 & $1.3 \mathrm{~B}$ & 1.2 & $2.6 \mathrm{~B}$ & 1.5 \\
\hline Litter depth $(\mathrm{cm})$ & $4.9 \mathrm{~A}$ & 0.3 & $4.0 \mathrm{~B}$ & 0.3 & $4.8 \mathrm{AB}$ & 0.4 \\
\hline Vegetation height $(\mathrm{cm})$ & $48.7 \mathrm{~A}$ & 1.0 & $33.2 \mathrm{~B}$ & 1.1 & $39.1 \mathrm{C}$ & 1.4 \\
\hline Visual obstruction (dm) & $3.8 \mathrm{~A}$ & 0.1 & $1.7 \mathrm{~B}$ & 0.1 & $2.1 \mathrm{~B}$ & 0.2 \\
\hline \multicolumn{7}{|l|}{ Distance $(m)$ of nest to } \\
\hline Shrubs & $11.0 \mathrm{~A}$ & 3.3 & $32.7 \mathrm{~B}$ & 3.7 & $36.8 \mathrm{~B}$ & 4.7 \\
\hline Trees & $99.2 \mathrm{~A}$ & 21.5 & $219.8 \mathrm{~B}$ & 24.3 & $192.9 \mathrm{~B}$ & 30.6 \\
\hline
\end{tabular}

We used average nest characteristics for each species, region, year, and study plot. excluding prairies in which $<5$ nests were found; $n=137$ plotyears for the analysis on nest substrate; $n=134$ for all other analyses.

b Nest substrate was defined as that on which $>50 \%$ of the nest was built.

Savannah Sparrows, and 29 May for Bobolinks (Fig. 1). Dates of nest initiation did not differ between Savannah Sparrows and Claycolored Sparrows $(P=1.00)$, whereas nest initiation for Bobolinks was about 2 weeks later than that of the other two species (both comparisons: $P<0.001, n=248$ ). Clay-colored Sparrows initiated most nests between mid-May and the end of June. For Savannah Sparrows, nest initiations were most frequent between late May and mid-June, but peaks in nest initiation were inconsistent among years and regions. Bobolinks initiated most of their nests from early to mid-June; almost no nests were initiated in July. The single nesting peak during a relatively short breeding season provides evidence for single-brooding of Bobolinks in our study region.

For each species, clutch size generally decreased during the breeding season (Fig. 2). The best model describing changes in clutch size included both linear and squared values of date. For Clay-colored Sparrows, the best model (Akaike weight $=0.83, n=582$ ) was more than nine times as well supported as the next best model that included the squared date alone (Akaike weight $=0.09$ ), whereas the best model for Savannah Sparrows (Akaike weight $=0.62$ ) was less than three times as well supported as the null model (Akaike weight $=0.23, n=387$ ). For Bobolinks, the best model (Akaike weight $=0.29, n=184$ ) did not clearly differ from models that included date as squared, linear, logarithmic, or linear plus exponential value (each model had an Akaike weight $>0.08$ ).

Probability of daily nest survival decreased with time during the breeding season in Claycolored Sparrows and Bobolinks (Fig. 3). The best model for both Clay-colored Sparrows (Akaike weight $=0.33, n=776$ ) and Bobolinks (Akaike weight $=0.40, n=312$ ) included the logarithmic transformation of date. Even though these models were better than the null model (which had an Akaike weight of zero), daily nest survival was not precisely estimated because of the large standard errors (Fig. 3). Linear and quadratic forms of date 

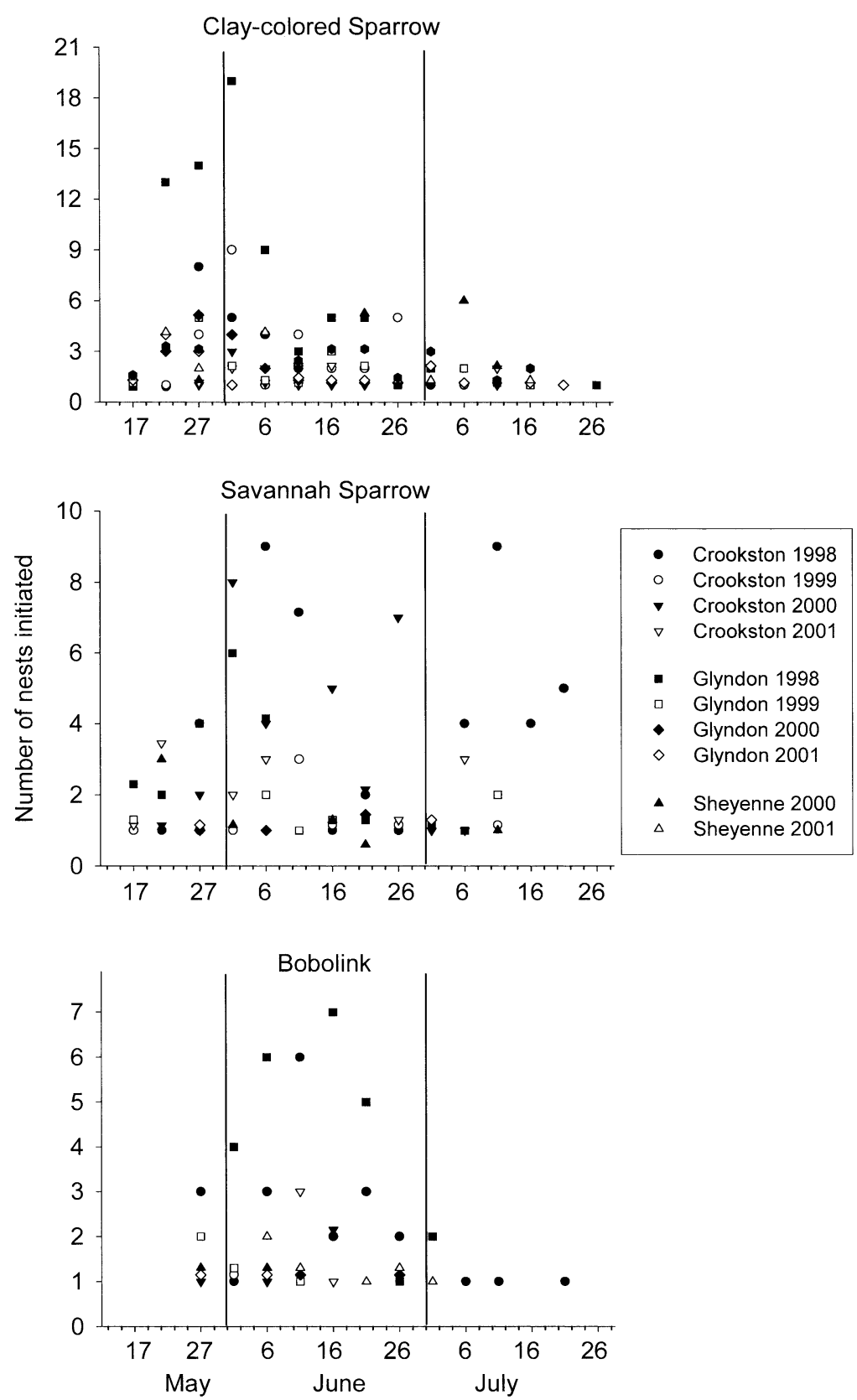

FIG. 1. Number of nests initiated within 5-day periods for three passerine species nesting in northern tallgrass prairie in Minnesota (Crookston and Glyndon regions) and North Dakota (Sheyenne National Grassland), 19982002. Dates of nest initiation were calculated by backdating from nests with known hatching or fledging dates; vertical lines distinguish the month in which nests were initiated.

were also well supported in both species (Akaike weight $>0.25$ ). Daily nest survival of Savannah Sparrows did not change with time in the breeding season (Fig. 3): the null model was better supported (Akaike weight $=$ $0.82, n=665$ ) than any model that included date.

The most important cause of nest failure 

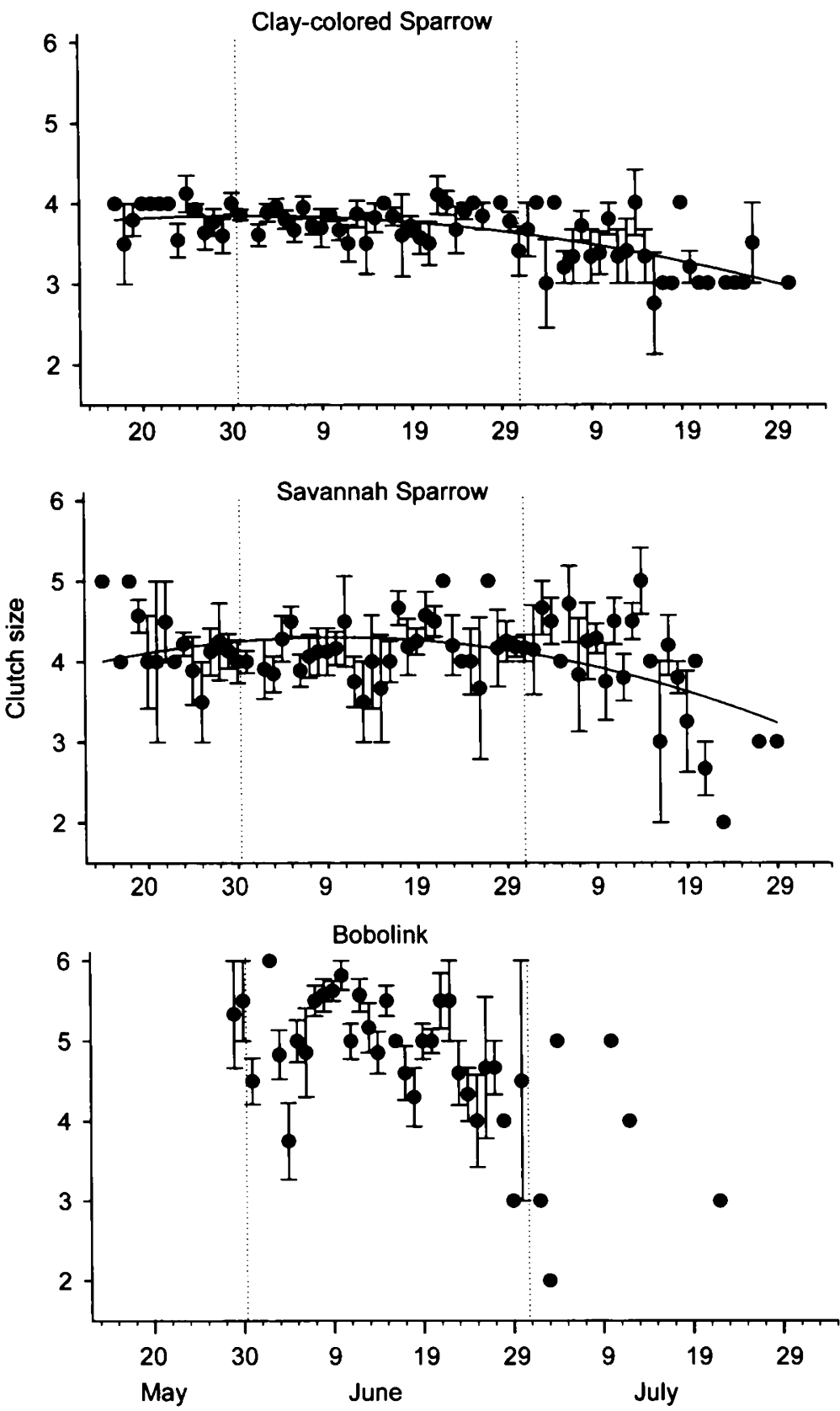

FIG. 2. Changes in clutch size during the breeding season for three species of grassland birds nesting in northern tallgrass prairie in Minnesota and North Dakota, 1998-2002. Each filled circle represents the mean clutch size ( $\pm \mathrm{SE}$ ) by date. Curves indicate predicted values for the best-fitting model that included date as a linear and squared term in a mixed model analysis. For Bobolinks, no line is shown because no single model best fit the data. 


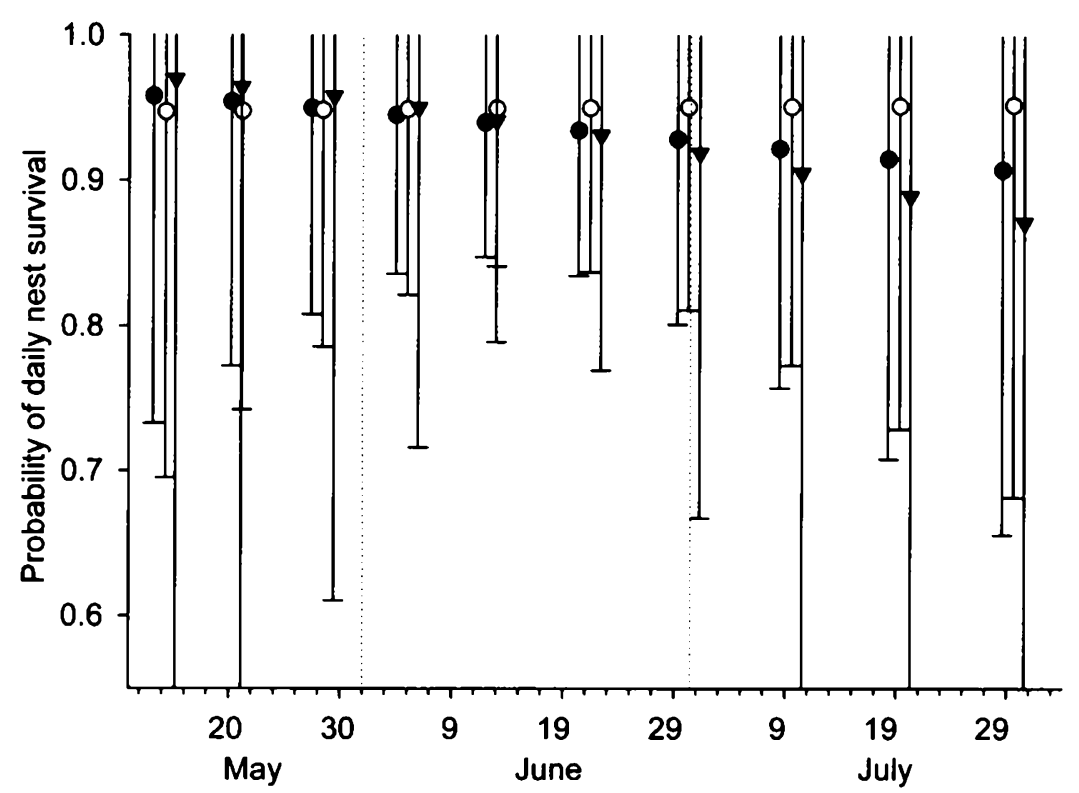

FIG. 3. Estimated daily nest survival (derived from the logistic-exposure method, Shaffer 2004) \pm SE for Clay-colored Sparrows (filled circles, $n=776$ nests), Savannah Sparrows (open circles, $n=665$ ), and Bobolinks (triangles, $n=312$ ) at different times during the breeding season in northern tallgrass prairie in Minnesota and North Dakota, 1998-2002.

was nest predation, followed by nest abandonment (Table 3). Nest predation was higher for Clay-colored Sparrows than for Savannah Sparrows, and was intermediate in Bobolinks. In only a few cases did hosts rear only cowbirds (Table 3 ). The percentage of abandoned nests was similar among species (each comparison: $P>0.05$ ), and its main cause-except for unknown factors-was partial nest predation (Table 3). However, we cannot be certain whether partial nest predation occurred before or after the nest was abandoned. Other causes of nest failure were of minor importance. Daily nest survival was highest for Savannah Sparrows, regardless of the estimation method (Table 4). Mayfield daily survival rates were slightly lower than those calculated with the logistic-exposure method (Table 4).

Clutch size was lowest for Clay-colored Sparrows and highest for Bobolinks (Fig. 2, Table 5). Even though the number of eggs hatched per nest was similar between Claycolored and Savannah sparrows, the number of host young fledged per nest was higher for Savannah Sparrows (Table 5), probably because nest predation was higher in Clay-colored Sparrows (Table 3). Compared with Sa- vannah Sparrows, Bobolinks had a larger clutch size and more eggs that hatched. In spite of this difference, the number of young fledged per nest was similar between Bobolinks and Savannah Sparrows, possibly because complete and partial nest predation were higher for Bobolinks than for Savannah Sparrows (Table 3).

Brood parasitism was lower for Clay-colored Sparrows than for Bobolinks $(P=0.017$, $n=135$ ), whereas it did not differ between Savannah Sparrows and either Clay-colored Sparrows or Bobolinks (each comparison: $P$ $>0.24$; Table 3). The number of cowbird eggs per parasitized nest was lower for Clay-colored Sparrows than for Savannah Sparrows $(P$ $=0.028, n=34$ ) but did not differ from that for Bobolinks $(P=0.64$; Table 5). Parasitized nests had smaller host clutch sizes than nonparasitized nests for Clay-colored Sparrows ( $t$ $=2.92, P=0.016, n=335$ ), Savannah Sparrows $(t=2.30, P=0.034, n=238)$, and Bobolinks $(t=1.79, P=0.077, n=103$; Table 5). For each species, the number of host eggs hatched in nonparasitized nests was higher than in parasitized nests (Clay-colored Sparrows: $t=3.55, P<0.001, n=393$; Sa- 
TABLE 3. Causes of egg and nestling mortality for three passerine species nesting in northern tallgrass prairie in Minnesota and North Dakota, 1998-2002. Means sharing the same letter (within rows) are not significantly different $(P>0.05)$.

\begin{tabular}{lccc}
\hline & $\begin{array}{c}\text { Clay-colored Sparrow } \\
(n=781)^{\mathrm{a}}\end{array}$ & $\begin{array}{c}\text { Savannah Sparrow } \\
(n=675)^{\mathrm{a}}\end{array}$ & $\begin{array}{c}\text { Bobolink } \\
(n=314)^{\mathrm{a}}\end{array}$ \\
\hline Complete nest loss due to & & & $41.8 \mathrm{AB}$ \\
$\quad$ Predation (\%) & $47.9 \mathrm{~A}$ & $33.5 \mathrm{~B}$ & $1.9 \mathrm{~A}$ \\
Weather (\%) & $1.4 \mathrm{~A}$ & $1.5 \mathrm{~A}$ & $2.5 \mathrm{~A}$ \\
Trampling (\%) & $1.3 \mathrm{~A}$ & $0.6 \mathrm{~A}$ & $1.6 \mathrm{~A}$ \\
Cowbird parasitism (\%) & $0.8 \mathrm{~A}$ & $1.5 \mathrm{~A}$ & $0.0 \mathrm{~A}$ \\
Burning (\%) & $0.4 \mathrm{~A}$ & $0.0 \mathrm{~A}$ & $8.0 \mathrm{~A}$ \\
Abandonment $(\%)^{\mathrm{c}}$ & $8.8 \mathrm{~A}$ & $6.4 \mathrm{~A}$ & 36.0 \\
$\quad$ Partial predation (\%) & 30.8 & 25.6 & 12.0 \\
$\quad$ Cowbird parasitism (\%) & 16.2 & 18.6 & 12.0 \\
$\quad$ Banding (\%) & 14.7 & 20.9 & 16.0 \\
$\quad$ Weather (\%) & 2.9 & 11.6 & 24.0 \\
$\quad$ Unknown cause (\%) & 35.4 & 23.3 & 1.0 \\
Unknown fate (\%) & 0.4 & 0.6 & $13.7 \mathrm{~B}$ \\
Partial predation at any nesting stage (\%) & $9.3 \mathrm{~A}$ & $9.5 \mathrm{~A}$ & $10.8 \mathrm{~B}$ \\
Cowbird parasitism (\%) & $5.1 \mathrm{~A}$ & $6.7 \mathrm{AB}$ & \\
\hline
\end{tabular}

a Number of nests used in the analysis.

b Nests were completely lost to cowbirds if cowbirds removed all eggs or young from the nest.

${ }^{c}$ Includes only those nests that were known to be abandoned or not (CCSP: $n=776$, SAVS: $n=668$, BOBO: $n=311$ ).

d As part of a study on annual return rates (T. M. Donovan unpubl. data), some birds were banded in the Crookston region.

e Percentage of nests parasitized by Brown-headed Cowbirds.

vannah Sparrows: $t=2.95, P<0.001, n=$ 302; Bobolinks: $t=1.89, P=0.061, n=123$; Table 5). Consequently, more host young fledged from nonparasitized than from parasitized nests (Clay-colored Sparrow: $t=5.77$, $P<0.001, n=778$; Savannah Sparrow: $t=$ 13.46, $P<0.001, n=669$; Bobolink: $t=$ 5.15, $P<0.001, n=313$; Table 5). Similar differences in the number of host young fledged were also found for nonparasitized and parasitized successful nests (in each comparison: $t>3.2, P<0.01$; Table 5).

\section{DISCUSSION}

The differences in breeding parameters among species that we studied suggest that one common management practice, the use of "indicator species," cannot be used indiscriminately in the conservation of grassland bird communities. Different management actions will benefit different sets of species. For example, early haying might not be detrimental to the relatively late-arriving Bobolink, but would destroy nests of Clay-colored and Savannah sparrows, whereas removal of shrubs

TABLE 4. Estimates of daily nest survival and nest success for three passerine species nesting in northern tallgrass prairie in Minnesota and North Dakota, 1998-2002.

\begin{tabular}{|c|c|c|c|}
\hline & Clay-colored Sparrow & Savannah Sparrow & Bobolink \\
\hline Number of nests & 793 & 687 & 315 \\
\hline Number of unsuccessful nests & 460 & 286 & 163 \\
\hline Exposure days & 7333.5 & 5456 & 2564 \\
\hline Days of nesting (interval length) ${ }^{\mathbf{a}}$ & 20 & 21.5 & 24 \\
\hline Mayfield daily nest survival rate $\pm S E^{\mathrm{b}}$ & $0.937 \pm 0.003$ & $0.948 \pm 0.003$ & $0.936 \pm 0.005$ \\
\hline Mayfield nest success ${ }^{c}$ & 0.274 & 0.314 & 0.207 \\
\hline Logistic-exposure daily nest survival rate $\pm S E^{d}$ & $0.940 \pm 0.092$ & $0.950 \pm 0.107$ & $0.939 \pm 0.144$ \\
\hline Logistic-exposure nest success ${ }^{c}$ & 0.288 & 0.330 & 0.219 \\
\hline
\end{tabular}

a Incubation and nestling days (Ehrlich et al. 1988).

b Mayfield daily nest survival rate $(D S R)=1-$ (number of unsuccessful nests/exposure days). SE $=$ sqrt $((D S R \times(1-D S R)) / e x p o s u r e$ days)

c Probability of nesting success over the incubation and nestling intervals $=$ DSR $^{\text {interval length }}$

d Probability of daily nest survival as calculated by the logistic-exposure model (Shaffer 2004). 
TABLE 5. Clutch size, hatching success, and fledging success ( \pm SE) of parasitized and nonparasitized nests of three passerine species nesting in northern tallgrass prairie in Minnesota and North Dakota, $1998-2002$. Means sharing the same letter (within rows) are not significantly different $(P>0.05)$.

\begin{tabular}{|c|c|c|c|c|c|c|c|c|c|}
\hline & \multicolumn{3}{|c|}{ Clay-colored Sparrow } & \multicolumn{3}{|c|}{ Savannah Sparrow } & \multicolumn{3}{|c|}{ Bobolink } \\
\hline & $\dot{x}$ & SE & $n$ & $\bar{x}$ & SE & $n$ & $\bar{x}$ & $\mathrm{SE}$ & $n$ \\
\hline Host clutch sizea & $3.77 \mathrm{~A}$ & 0.03 & 335 & $4.13 \mathrm{~B}$ & 0.05 & 238 & $5.25 \mathrm{C}$ & 0.08 & 103 \\
\hline Nonparasitized nests & $3.80 \mathrm{~A}$ & 0.03 & 325 & $4.19 \mathrm{~B}$ & 0.05 & 220 & $5.29 \mathrm{C}$ & 0.08 & 97 \\
\hline Parasitized nests & $3.10 \mathrm{~A}$ & 0.23 & 10 & $3.50 \mathrm{AB}$ & 0.29 & 18 & $4.67 \mathrm{~B}$ & 0.49 & 6 \\
\hline Number of cowbird eggs & $1.00 \mathrm{~A}$ & 0.00 & 10 & $1.50 \mathrm{~B}$ & 0.12 & 18 & $1.33 \mathrm{AB}$ & 0.21 & 6 \\
\hline Host eggs hatched/nest ${ }^{\mathrm{b}}$ & $2.52 \mathrm{~A}$ & 0.09 & 393 & $2.41 \mathrm{~A}$ & 0.11 & 302 & $3.46 \mathrm{~B}$ & 0.20 & 123 \\
\hline Nonparasitized nests & $2.59 \mathrm{~A}$ & 0.09 & 372 & $2.49 \mathrm{~A}$ & 0.12 & 280 & $3.57 \mathrm{~B}$ & 0.21 & 114 \\
\hline Parasitized nests & $1.24 \mathrm{~A}$ & 0.29 & 21 & $1.32 \mathrm{~A}$ & 0.27 & 22 & $2.11 \mathrm{~A}$ & 0.75 & 9 \\
\hline Host young fledged/nest & $1.35 \mathrm{~A}$ & 0.06 & 778 & $2.01 \mathrm{~B}$ & 0.07 & 669 & $1.97 \mathrm{~B}$ & 0.13 & 313 \\
\hline Nonparasitized nests & $1.40 \mathrm{~A}$ & 0.06 & 738 & $2.13 \mathrm{~B}$ & 0.08 & 624 & $2.12 \mathrm{~B}$ & 0.14 & 279 \\
\hline Parasitized nests & $0.45 \mathrm{~A}$ & 0.15 & 40 & $0.33 \mathrm{~A}$ & 0.11 & 45 & $0.71 \mathrm{~A}$ & 0.24 & 34 \\
\hline Host young fledged/successful nest & $3.28 \mathrm{~A}$ & 0.05 & 320 & $3.50 \mathrm{~A}$ & 0.05 & 385 & $4.11 \mathrm{~B}$ & 0.12 & 150 \\
\hline Nonparasitized nests & $3.32 \mathrm{~A}$ & 0.05 & 311 & $3.55 \mathrm{~B}$ & 0.05 & 375 & $4.21 \mathrm{C}$ & 0.12 & 141 \\
\hline Parasitized nests & $2.00 \mathrm{~A}$ & 0.33 & 9 & $1.50 \mathrm{~A}$ & 0.27 & 10 & $2.67 \mathrm{~A}$ & 0.47 & 9 \\
\hline
\end{tabular}

a Clutch size was determined only for nests that were monitored during incubation.

${ }^{b}$ Hatching success was determined only for nests that were monitored during both the incubation and nestling stages.

would benefit Bobolinks and Savannah Sparrows but limit Clay-colored Sparrows. If any of these species were used as indicator species for developing management guidelines, other species would be mismanaged. Grassland management therefore needs to incorporate the most important aspects of the breeding ecology of each species of interest. Baseline and species-specific data-as provided in our study - are needed to understand which aspects are most important to consider for management actions in a certain area.

Not surprisingly, nest-site characteristics of Savannah Sparrows and Bobolinks were more similar to each other than to those of Claycolored Sparrows. Clay-colored Sparrows are more a shrubland species than a pure grassland species (Knapton 1994). Savannah Sparrows and Bobolinks, on the other hand, prefer nesting within dense clumps of litter and grass (Dechant et al. 2003b, Dieni and Jones 2003, Swanson 2003). Despite the similar nest-site requirements of Savannah Sparrows and Bobolinks, several nest-site characteristics differed (Table 2), indicating that management practices will differentially affect even those species that have seemingly similar habitat requirements.

The timing of nesting differed markedly between the two grassland sparrows and Bobolinks, with Bobolinks nesting about 2 weeks later than Clay-colored and Savannah spar- rows. Double-brooding has been reported previously for Clay-colored Sparrows (Knapton 1978) and Savannah Sparrows (Lein 1968, Wiens 1969, Wheelwright and Rising 1993), and the long breeding season (Fig. 1) at our study area makes it likely that Clay-colored and Savannah sparrows raised two broods there as well. For Bobolinks, the breeding season is probably too short for raising two broods (see Gavin 1984). Even though Claycolored Sparrows fledged less than two young per nest at our study sites (Table 5), doublebrooding might result in high-enough seasonal fecundity to ensure population survival. Clutch sizes were similar to those reported elsewhere (Wheelwright and Rising 1993, Martin and Gavin 1995, Swanson 1996, Davis 2003). In each species, clutch size generally decreased during the breeding season, as is well known for many passerines (Dhondt et al. 2002).

Daily nest survival decreased during the breeding season in Clay-colored Sparrows and Bobolinks, but did not change noticeably in Savannah Sparrows. The model including log (date) was the best of those we tested, but there was considerable variation in our estimates (Fig. 3). Differences among species in timing of breeding and in changes of clutch size and daily nest survival over the season indicate that there is no certain time period in which the entire grassland bird community is 
least susceptible to disturbances. Certainly, the best timing for any management is before the main nesting season starts (mid-May) or after the main nesting season is over (early August) to minimize disturbances to clutches, young, and fledglings.

In our study, the percentage of successful Clay-colored Sparrow nests was generally higher $(28.8 \%)$ than that reported in most other areas studied: $13.9 \%$ of nests were successful in Saskatchewan $(n=84$; Davis $2003)$, and $25.5 \%(n=49)$ and $52.2 \%(n=$ 24) of all nests were successful in Waterfowl Production Areas in North Dakota and Minnesota, respectively (Koford 1999, data recalculated for incubation and nestling period only). Nest success of Savannah Sparrows in our study $(33.0 \%)$ was higher than that reported for Saskatchewan $(22.7 \%, n=84$; Davis 2003) and Manitoba (7\%, $n=30$; Davis and Sealy 2000), and was similar to that reported in Waterfowl Production Areas in Minnesota (33.2\%, $n=30$; Koford 1999). For Bobolinks, nest success was lower in Minnesota $(14.2 \%$ and $15.8 \%$ in two types of planted cover, total $n=47$; Koford 1999) than in our study (21.9\%). Higher Bobolink nest success was reported for New York $(54.5 \%, n=$ 422; Martin and Gavin 1995) and Wisconsin $(52.4 \%, n=103$; Martin 1971), but those values are apparent rates of nest success, which are biased high, possibly by a factor of two (Johnson 1979). Most of the nest failures documented in our study were due to predation, similar to what was found by Martin (1993) and Davis (2003).

Brood parasitism is assumed to be higher close to shrubs and trees because woody vegetation may harbor more Brown-headed Cowbirds (Johnson and Temple 1990, Romig and Crawford 1995, Saunders et al. 2003). Because nests of Clay-colored Sparrows were closer to woody vegetation and were higher off the ground than nests of Savannah Sparrows and Bobolinks (Table 2), we expected Clay-colored Sparrows to have higher rates of brood parasitism than the other two species (Fleischer 1986, Davis and Sealy 2000). However, brood parasitism by cowbirds was lower in Clay-colored Sparrows (5.1\%) than in Bobolinks $(10.8 \%)$, whereas in Savannah Sparrows it was intermediate $(6.7 \%)$. Larger birds might be more conspicuous than more-secre- tive grassland sparrows, facilitating detection by female cowbirds (Davis and Sealy 2000, Koford et al. 2000). However, Bobolink-the largest grassland bird in our study-is also an icterid, and a preference of cowbirds for icterine species might have a phylogenetic basis (Hanka 1979).

Clay-colored Sparrows had lower parasitism $(5.1 \%)$ than that reported for any other area (range: 10-39\%; Shaffer et al. 2003). Similarly, brood parasitism in Savannah Sparrows was lower $(6.7 \%)$ than that reported in most other studies (range: 2-37\%; Shaffer et al. 2003). Brood parasitism of Bobolinks $(10.8 \%)$ was intermediate to that recorded in other studies (range: $0-34 \%$; Shaffer et al. 2003). Even though parasitized nests fledged one to two fewer young than nonparasitized nests, cowbirds probably do not have a significant effect on grassland bird populations in our study area because the intensity of parasitism there is low.

Several factors might be responsible for low levels of nest predation and cowbird parasitism found in our study area (MW unpubl. data). Some of the most likely factors were (1) study plots were located in relatively large patches of continuous grassland [median = 61.3 ha, 8.0-1,245.6 ha (5th-95th percentile)], and nest predation and cowbird parasitism is frequently lower in large grassland patches (Winter and Faaborg 1999, Herkert et al. 2003); (2) study plots were located in a landscape with relatively little shrub and tree cover within $1 \mathrm{~km}$ [median $=9.6 \%, 1.5-29.3 \%$ (5th-95th percentile)], and nest predation and cowbird parasitism is frequently lower far from woody vegetation (Johnson and Temple 1990, Davis and Sealy 2000, Winter et al. 2000); and (3) few cattle were present in the study area (except for Sheyenne National Grassland), and cowbird parasitism is frequently lower far from grazed areas (Davis and Sealy 2000, Goguen and Mathews 2000). Proximity of our study area to the center of the cowbird's range (Lowther 1993) may not result in high brood parasitism, because cowbird parasitism can be largely independent of cowbird density (Goguen and Matthews 2000).

In summary, grassland birds in our study area appear to be more successful than in most other areas where their nesting parameters 
have been investigated; nest success was higher, and cowbird parasitism was lower than in most other studies. Northwestern Minnesota and southeastern North Dakota provide some of the largest remaining tracts of native tallgrass prairie, many of which are surrounded by large tracts of reseeded grasslands and little forest cover (MW unpubl. data). These features probably contribute to quality habitats for nesting grassland birds.

\section{ACKNOWLEDGMENTS}

Thanks to the numerous field assistants who helped find grassland bird nests and to T. M. Donovan, who cooperated on this project. Numerous comments by $S$. K. Davis, R. B. Renfrew, and two anonymous reviewers greatly improved the manuscript. This project was funded by the U.S. Geological Survey and the U.S. Fish and Wildlife Service, Regions 3 and 6.

\section{LITERATURE CITED}

Anderson, D. R., K. P. Burnham, AND W. L. ThompsoN. 2000. Null hypothesis testing: problems, prevalence, and an alternative. Journal of Wildlife Management 64:912-923.

DAUBENMIRE, R. 1959. A canopy-coverage method of vegetational analysis. Northwest Scientist 33:4364.

DAVIS, S. K. 2003. Nesting ecology of mixed-grass prairie songbirds in southern Saskatchewan. Wilson Bulletin 115:119-130.

Davis, S. K. and S. G. Sealy. 2000. Cowbird parasitism and nest predation in fragmented grasslands of southwestern Manitoba. Pages 220-228 in Ecology and management of cowbirds and their hosts (J. N. M. Smith, T. L. Cook, S. I. Rothstein, S. K. Robinson, and S. G. Sealy, Eds.). University of Texas Press, Austin.

Dechant, J. A., M. L. Sondreal, D. H. Johnson, L. D. IGL, C. M. Goldade, M. P. Nenneman, AND B. R. EuLiss. 2003a. Effects of management practices on grassland birds: Clay-colored Sparrow, ver. 12DEC2003. Northern Prairie Wildlife Research Center, Jamestown, North Dakota. Online at <http://www.npwrc.usgs.gov/resource/literatr/ grasbird/ccsp/ccsp.htm > (accessed 10 February 2004).

Dechant, J. A., M. L. Sondreal, D. H. Johnson, L. D. Igl, C. M. Goldade, A. L. Zimmerman, AND B. R. Euliss. 2003b. Effects of management practices on grassland birds: Bobolink, ver. 12DEC2003. Northern Prairie Wildlife Research Center, Jamestown, North Dakota. Online at <http://www.npwrc.usgs.gov/resource/literatr/ grasbird/bobo/bobo.htm > (accessed 10 February 2004).

Dhondt, A. A., T. L. Kast, and P. E. Allen. 2002. Geographical differences in seasonal clutch size variation in multi-brooded bird species. Ibis 144: 646-651.

Dieni, J. S. AND S. L. JoNES. 2003. Grassland songbird nest site selection patterns in northcentral Montana. Wilson Bulletin 115:388-396.

Dixon, C. L. 1978. Breeding biology of the Savannah Sparrow on Kent Island. Auk 95:235-246.

EhrLiCH, P. R., D. S. DobKIN, AND D. WheYe. 1988. The birder's handbook. Simon and Schuster, New York.

FLeISCHER, R. C. 1986. Brood parasitism by Brownheaded Cowbirds in a simple host community in eastern Kansas. Kansas Ornithological Society Bulletin 37:21-29.

Gavin, T. A. 1984. Broodedness in Bobolinks. Auk 101:179-181.

Goguen, C. B. AND N. E. MATHEws. 2000. Local gradients of cowbird abundance and parasitism relative to livestock grazing in a western landscape. Conservation Biology 14:1862-1869.

HANKA, L. R. 1979. Choice of host nest by the Brownheaded Cowbird in Colorado and Wyoming. Condor 81:436-437.

Herkert, J. R., D. L. Reinking, D. A. Wiedenfeld, M. Winter, J. L. Zimmerman, W. E. JenSEN, E. J. FincK, R. R. Koford, D. H. Wolfe, S. K. SheRROD, M. A. JENKINS, J. FAABorG, AND S. K. RoBINSON. 2003. Effects of prairie fragmentation on the nest success of breeding birds in the mid-continental United States. Conservation Biology 17: 587-594.

JohnSON, D. H. 1979. Estimating nest success: the Mayfield method and an alternative. Auk 96:651661.

Johnson, R. G. AND S. A. Temple. 1990. Nest predation and brood parasitism of tallgrass prairie birds. Journal of Wildlife Management 54:106-111.

KNAPTON, R. W. 1978. Breeding ecology of the Claycolored Sparrow. Living Bird 17:137-158.

KNAPTON, R. W. 1994. Clay-colored Sparrow (Spizella pallida). The Birds of North America, no. 120.

KOFORD, R. R. 1999. Density and fledging success of grassland birds in Conservation Reserve Program fields in North Dakota and west-central Minnesota. Studies in Avian Biology 19:187-195.

Koford, R. R., B. S. BOWEN, J. T. LOKEMOEN, AND A. D. KRUSE. 2000. Cowbird parasitism in grassland and cropland in the northern Great Plains. Pages 229-235 in Ecology and management of cowbirds and their hosts (J. N. M. Smith, T. L. Cook, S. I. Rothstein, S. K. Robinson, and S. G. Sealy, Eds.). University of Texas Press, Austin.

LEIN, M. R. 1968. The breeding biology of the Savannah Sparrow, Passerculus sandwichensis (Gmelin), at Saskatoon, Saskatchewan. M.A. thesis, University of Saskatchewan, Saskatoon, Canada.

LowTHER, P. E. 1993. Brown-headed Cowbird (Molothrus ater). The Birds of North America, no. 47.

Manolis, J. C., D. E. Andersen, And F. J. Cuthbert. 2000. Uncertain nest fates in songbird studies and 
variation in Mayfield estimation. Auk 117:615626.

MARTIN, S. G. 1971. Polygyny in the Bobolink: habitat quality and the adaptive complex. Ph.D. dissertation, Oregon State University, Corvallis.

Martin, S. G. ANd T. A. Gavin. 1995. Bobolink (Dolichonyx oryzivorus). The Birds of North America, no. 176.

MARTIN, T. E. 1993. Nest predation among vegetation layers and habitat types: revising the dogmas. American Naturalist 141:897-913.

MAYField, H. F. 1975. Suggestions for calculating nest success. Wilson Bulletin 87:456-466.

Peterjohn, B. G. and J. R. Sauer. 1999. Population status of North American grassland birds from the North American Breeding Bird Survey, 19661996. Studies in Avian Biology 19:27-44.

Pietz, P. J. AND D. A. Granfors. 2000. Identifying predators and fates of grassland passerine nests using miniature video cameras. Journal of Wildlife Management 64:71-87.

Robel, R. J., J. N. Briggs, A. D. Dayton, AND L. C. HULBERT. 1970. Relationship between visual obstruction measurements and weight of grassland vegetation. Journal of Range Management 23: 295-297.

Romig, G. P. AND R. D. CRAwFORD. 1995. Clay-colored Sparrows in North Dakota parasitized by Brownheaded Cowbirds. Prairie Naturalist 27:193-203.

SAS InSTITUTE, INC. 1999. The SAS system for Windows, ver. 8.0. SAS Institute, Inc., Cary, North Carolina.

Sauer, J. R., J. E. Hines, and J. Fallon. 2003. The North American Breeding Bird Survey, results and analysis 1966-2002, ver. 2003.1. USGS Patuxent Wildlife Research Center, Laurel, Maryland. Online at <http://www.mbr-pwrc.usgs.gov/ bbs/bbs2002.html > (accessed 1 June 2004).

SAunders, C. A., P. ARCese, and K. D. O'Connor. 2003. Nest site characteristics in the Song Sparrow and parasitism by Brown-headed Cowbirds. Wilson Bulletin 115:24-28.

Shaffer, J. A., C. M. Goldade, M. F. Dinkins, D. H. JoHNSON, L. D. IGL, AND B. R. Euliss. 2003. Brown-headed Cowbirds in grasslands: their habitats, hosts, and response to management. Prairie Naturalist 35:145-186.

ShaFFer, T. L. 2004. A unified approach to analyzing nest success. Auk 121:526-540.

Swanson, D. A. 1996. Nesting ecology and nesting habitat requirements of Ohio's grassland-nesting birds: a literature review. Ohio Fish and Wildlife Report, no. 13, Columbus, Ohio.

Swanson, D. A. 2003. Effects of management practices on grassland birds: Savannah Sparrow, ver. 12DEC2003. Northern Prairie Wildlife Research Center, Jamestown, North Dakota. Online at <http://www.npwrc.usgs.gov/resource/literatr/ grasbird/savs/savs.htm > (accessed 10 February 2004).

Wheelwright, N. T. AND R. A. MAuCK. 1998. Philopatry, natal dispersal, and inbreeding avoidance in an island population of Savannah Sparrows. Ecology 79:755-767.

WheElWRIGHT, N. T. AND J. D. Rising. 1993. Savannah Sparrow (Passerculus sandwichensis). The Birds of North America, no. 45.

WiENS, J. A. 1969. An approach to the study of ecological relationships among grassland birds. Ornithological Monographs, no. 8. American Ornithologists' Union, Washington, D.C.

WINTER, M. 1999. Nesting behavior and nest success of Henslow's Sparrows and Dickcissels in southwestern Missouri prairie fragments. Wilson Bulletin 111:515-527.

WINTER, M. AND J. FAABORG. 1999. Varying patterns of area-sensitivity in grassland-nesting birds. Conservation Biology 13:1324-1434.

Winter, M., S. E. Hawks, J. A. Shaffer, AND D. H. JoHNSON. 2003. Guidelines for finding nests of passerine birds in tallgrass prairie. Prairie Naturalist 35:197-211.

Winter, M., D. H. Johnson, J. A. Dechant, T. M. Donovan, AND W. D. Svedarsky. 2001. Evaluation of the Bird Conservation Area concept in the northern tallgrass prairie. Annual report for the U.S. Department of Interior, U.S. Geological Survey, Northern Prairie Wildlife Research Center, Jamestown, North Dakota. Online at <http:// www.npwrc.usgs.gov/resource/2002/bca2001/ bca2001.htm > (accessed 8 February 2004).

Winter, M., D. H. Johnson, AND J. FAaborg. 2000. Evidence of edge effects on multiple levels in tallgrass prairie. Condor 102:256-266.

Winter, M., D. H. Johnson, AND J. A. ShafFer. In press. Variability in vegetation effects on density and nesting success of grassland birds. Journal of Wildlife Management.

WOlfINGER, R. AND M. O'ConNell. 1993. Generalized linear mixed models: a pseudo-likelihood approach. Journal of Statistical Computation and Simulation 48:233-243. 